\title{
Near, far: the beginning of a twenty-first century Progressive Era in the US?
}

\author{
Wenli Zhu ${ }^{1}$ \\ Received: 4 January 2021 / Accepted: 19 March 2021 / Published online: 9 April 2021 \\ (C) The Institute of International and Strategic Studies (IISS), Peking University 2021
}

\begin{abstract}
Representatives of American progressives and their policy propositions suffered unexpected setbacks in the early stages of the 2020 US presidential election. Unlike progressives during the Progressive Era in the early twentieth century, progressives in the US today have been directly confronted by those they intend to challenge and have failed to win over middle- and lower-class white Americans in inland towns and villages. Despite an enthusiastic response from younger generations and extensive support among the suburban middle class and ethnic minorities, they have been unable to foster synergy due to subtle differences in their reformist agendas. Adverse factors, such as the inherent deficiencies of the American political system in dealing with the challenges of globalization, the fragmentation of public opinion caused by the development of new technologies, and a growing sentiment among Americans to stay out of the trends in world politics, also hinder progressive propositions. Achieving a political revitalization like the one over a hundred years ago will be no easy task.
\end{abstract}

Keywords Progressive politics · US presidential election - Trends in world politics

\section{Introduction}

The 2020 US election attracted worldwide attention, but the real policy debate ended long before the final duel between the two parties' candidates. The dramatic debates between Donald Trump and Joe Biden appealed more to the feelings than the minds of Americans. In November 2020, American voters had to decide by ballot whether they wanted continued division, disputes, and confrontation, or reflection, communication, and reconciliation. Therefore, the best result of the election is to stop losses and to first return to normal in the political field amidst the social and economic

Wenli Zhu

zhuwenli@pku.org.cn

1 Professor at School of International Relations, Peking University, No.5 Yiheyuan Road Haidian District, Beijing 100871, People's Republic of China 
chaos caused by the COVID-19 pandemic. While Americans wait anxiously for this minimum requirement to be fulfilled, real policy innovation and political progress have been quietly put on the shelf.

More than a century ago, American political institutions demonstrated sufficient flexibility and stability when challenged by economic modernization and massive immigration. From the Progressive Era to the New Deal, bold yet practical reforms were adopted to alleviate socioeconomic inequality, laying a reliable foundation for the sustained growth of national strength. This, in turn, enabled the United States' dominant position in the games to reshape the world. In contrast, while the US faces similar challenges today, its political processes have not been able to focus on real problems or deal with them effectively, and in many cases, they have fueled conflicts. New progressives have often appeared late in political discussions and have so far failed to take the central stage. They have thus lost the opportunity to champion changes in the 2020 general election. This paper attempts to conduct a preliminary review and analysis of factors that either promote or hinder the American progressive movement and discuss the relevance of political choices in the US to world politics.

\section{The defeat of the progressives during the 2020 election}

In retrospect, the social foundation of American progressives in the twenty-first century, whose political representatives emerged during the 2016-2020 election cycle, can be traced back to the Occupy Wall Street movement (OWS) in 2011. OWS, partially in response to the rightist Tea Party, put forward a tit-for-tat interpretation of the root causes of the global financial crisis and focused on the economic and social inequality caused by globalization. Later, the Black Lives Matter movement (BLM), \#MeToo movement, and March for Our Lives contributed to the expansion of the progressive camp. Though their agendas focus on more social and cultural topics, their core logic aligns with that of OWS: economic inequality has caused social tension and conflict; traditional political topics have overlooked the real problems; and comprehensive progressive reforms are needed to renew American politics.

In 2016, Bernie Sanders renounced his status as an independent and joined the Democratic presidential primary with a comprehensive progressive political agenda. His innovative platform was warmly received and posed a substantial challenge to Hillary Clinton. Although Sanders did not win the Democratic nomination, he shocked American political circles as a symbol of political reform. Trump's unexpected election dealt a great blow to the establishment of both parties, but at the same time, it stimulated and inspired progressives' demands for change and provided opportunities for a greater number of progressive representatives to compete for and take office. During the 2018 midterm elections, a group of new politicians stood out with their calls for social, cultural, and economic reforms. Among them, 29-year-old Alexandria Ocasio-Cortez (AOC) from New York attracted national attention with her active presence in discussions of hot issues. By the primary stage of the 2020 election, Sanders was joined by Massachusetts Senator Elizabeth Warren, a steady reformist; Senator Kirsten Gillibrand, an early supporter of the \#MeToo movement; 
and Andrew Yang, a Chinese American entrepreneur who advocated universal basic income. Various progressive proposals served as their hit campaign themes. At least within the Democratic Party, political representatives and grassroots movements gradually vibrated in resonance with each other.

The television debates in the second half of 2019 and early 2020 can be regarded as the first stage of the Democratic primary, during which progressive campaigners gained momentum. Their policy ideas, such as Medicare for All, free university education, higher minimum wage, and environmental protection, became hot topics of discussion. Sanders and Warren attracted a large number of supporters and took turns leading in the polls due to their clear standpoints, understanding of the realities of grassroots life, and advocacy for change. In contrast, former Vice President Biden, the most visible candidate and favorite to win the primary, struggled to mobilize the enthusiasm of grassroots voters. As the debates continued, Biden's support gradually declined, and he sank to fourth among the Democratic candidates in the polls.

However, as the progressives took the lead in the primary, doubts and criticisms grew within and without the Democratic Party. Their policy proposals were considered too ambitious and costly for existing institutions to accommodate and afford. Some fierce critics even claimed the proposals threatened to overstretch federal power or destroy the US economy. Senator Warren, who had once led the polls, met her Waterloo in the headwinds of these challenges. The details of her Medicare for All plan were repeatedly questioned. Some mainstream media outlets claimed that the actual cost of the plan would far exceed the figures announced by the Warren team (Peoples 2019; Kurtzleben 2019). Warren then lost her leading position and momentum, and never came back from that loss (Khalid 2020).

In spring 2020, when the Democratic primary entered its second stage, with voting held in states, Bernie Sanders became the only hope for progressives. Sanders won the first two small states, but Biden won South Carolina with the public support of local black leaders. Later, on Super Tuesday, Biden swept through southern states where local Black caucuses overwhelmed, and moderate candidates who fell behind suspended their campaigns and called on their supporters to support Biden. As a result, a quasi-coalition of Democratic establishment figures emerged. In midMarch, Sanders and Biden directly competed against each other in the critical Rust Belt states in the Great Lakes area, and Biden won an overwhelming victory. The COVID-19 pandemic then broke out in the US. Because it was no longer possible to organize large-scale grassroots rallies to save his campaign, Sanders had to suspend his campaign.

A review of Sanders' defeat in the Democratic primary points to his failures to win over the black community and to establish an advantage in traditional manufacturing areas as the main reasons for his loss. The former reflects the complex challenges of cultural identity; though Sanders is very popular among Latino Democratic voters, he has been criticized by black leaders for not focusing on fighting discrimination and helping poverty-stricken communities. The latter indicates a more subtle weakness of the progressive agenda. Sanders strongly advocated expanding higher education to improve human capital and driving economic transformation with environmental protection and new energy industries so that old industrial 
zones, such as the Great Lakes area, can smoothly join the booming service sector. Blue-collar workers represented by manufacturing trade unions did not seem to be convinced by Sanders' pitch. In contrast, Biden emphasized his childhood in a small Pennsylvania town, expressed his personal understanding of industrial and regional difficulties, and successfully impressed grassroots voters with simple and direct slogans such as stopping outsourcing, increasing employment, and buying American goods. The defeat in the 2016 presidential election had been a painful lesson for the Democratic Party. If progressives cannot penetrate inland towns and win the acceptance of key voters in battleground states, they will lose the opportunity to represent the Democratic Party on the national stage.

Shortly after Biden secured the Democratic nomination, his campaign team began to work closely with the Sanders team, and the Democratic primary entered its third stage, shifting from intra-party competition to cooperation. In May 2020, Biden and Sanders formally announced the creation of their Unity Task Forces, involving AOC, former Secretary of State John Kerry, and other public figures, to coordinate positions on six key domestic issues. The results of these negotiations were submitted to the Democratic National Convention as a consensus proposal and became the basic content of the Democratic Party's program (Forgey 2020; Nilsen 2020). The final party program covered all the main concerns of the progressives, such as building a fair economy, promoting environmental protection and climate policies, and improving the US medical insurance system. However, with regard to specific steps for implementation, the steady rhythms of the establishment overwhelmed the progressives' desire for more aggressive changes (Tarlov 2020; Prokop 2020; Democratic National Convention 2020). As a result of negotiation and compromise, the progressives' substantive policy propositions were watered down and weakened, and there was little chance for implementation in the short term. As Biden clearly stated in the first bipartisan presidential debate: "Right now, I am the Democratic Party." In other words, the progressives lost the opportunity to initiate political changes in the 2020 general election.

\section{Forces driving progressive politics}

In light of the political cycle described by Samuel Huntington, the renowned American political scientist, 2020 should hopefully be an important point in history for innovation and change in US politics (Huntington 2017). Indeed, the progressive politics of the tweny-first century has, since its budding in the OWS movement, accumulated sufficient momentum to change the political map.

The core groups championing the progressive movement in the US today are the millennials (born between 1982 and 2000) ${ }^{1}$ and Generation Z (born after 2000). The year 2020 was the first general election in which all millennials were

\footnotetext{
1 There are different opinions about the starting year for millennials (or Generation Y) in the United States. Every year from 1978 to 1982 has been used as the starting year in various statistics and analyses, with varying corresponding population sizes.
} 
of legal voting age. Of the total millennial population of more than 100 million, 90 million are eligible voters, accounting for nearly $40 \%$ of all voters in the US. An extrapolation based on previous turnouts of young people suggests that over 50 million millennials voted in the 2020 election, accounting for about $36 \%$ of all voters (Teixeira 2010). Although most of Generation $\mathrm{Z}$ did not have the right to vote in 2020, many of its members had already been very active in social movements in the preceding years, such as climate change demonstrations and the nationwide gun control demonstrations triggered by the Stoneman Douglas High School shooting in Parkland, Florida. Moreover, according to US media reports, eligible Generation $\mathrm{Z}$ voters were $10 \%$ more ready to turn out than the 18-20 age group in previous elections. Their enthusiasm for politics was surprisingly high (Alcindor 2020).

Various social surveys and media reports have shown that the most prominent political inclination among members of young generations is a concern for social and economic inequality and support for policy innovation and institutional changes. Born and raised after the Civil Rights Movement, they generally embrace racial diversification and equality as a basic norm and sincerely support equal social and cultural rights reforms. During the 2008 US presidential election, millennials who had the right to vote supported Barack Obama with a substantial 64\% majority (Pew Research Center 2008), which played a key role in the election of the first president of color in American history. After the outbreak of the global financial crisis, the focus of young people shifted from cultural to economic issues. Many of them bore heavy university tuition loans and entered the job market during the economic downturn. Their job stability, salary, and career prospects were obviously less promising compared to those of their predecessors and their quality of life was far below expectation. Personal setbacks have given rise to doubts about the market's ability to distribute wealth. On this basis, many young people welcome government intervention and call for public policies to address inequalities. The right-wing conservative narrative that opposes big government, present since the Reagan Revolution, is no longer convincing for the young generations. They blame excessive deregulation for the spread of greed and arrogance among the supremely rich, which caused the financial tsunami in 2007-2008 and has forced the middle and lower classes, including young people, to bear the consequences. Sanders and other progressive leaders advocate the systemic reforms - such as waiving tuition loans, raising the minimum wage, and guaranteeing health insurance - that are precisely the issues of most concern to young people, thus earning their strong support. AOC and other activists have thus gone into politics with bold propositions. These new progressives follow Sanders and avow themselves "democratic socialists". The various taboos left over from the ideological competition during the Cold War are bygones for them (Robinson 2020). In their minds, "Canadian health insurance plus Swedish welfare" is the ideal socialist model. According to a Gallup poll conducted in the summer of 2019, $58 \%$ of young respondents (aged 18-34) believe that such socialist policies may be beneficial to the US (Palmer 2019). When some scholars call these reforms "progressive capitalism" (Brown and Sallstrom 2019), these young people likely have no objection; for them, the outdated ideological label is far less relevant than the substance and effect of the policies. 
In addition to the young generations, supporters of progressive politics in the new century include two other key groups. The first one is composed of members of ethnic minorities eager to seek social and economic security. Minority communities have disproportionately suffered from the ongoing economic crisis caused by the COVID-19 pandemic and the 2008 financial crisis (Cassella 2020). Longstanding and deep-rooted racial prejudice in society has reinforced their predicament. Moreover, indifference to and even contempt for the basic civil rights of minorities still pervade American police and judicial systems, intensifying minorities' resentment toward unfair treatment. After the Trump administration came to office, it repeatedly tightened US immigration policy and held an ambiguous attitude on racial issues. When racial discrimination led to social protests, the administration tended to impose harsh crackdowns without giving any heed to the causes for the unrest. Some of its public statements even favored white supremacists who had taken advantage of such opportunities to cause trouble. These attitudes and policies have further motivated ethnic minorities to advance institutional change. Arizona's political shift over recent elections is a typical example of this (PBS Newshour 2020). The state was formerly a staunch red state favoring the Republican Party, voting for the Democratic candidate in only one presidential election since 1952. However, stimulated by a state bill to arrest illegal immigrants, Hispanic communities mobilized a bottom-up action network to defeated renowned Republican candidates for Congress and police departments in the 2018 midterm elections and helped Biden win the state in the 2020 presidential election.

The other group that has received considerable attention is the suburban middle class. More than 40 years ago, "suburbs" was a synonym for "conservative stronghold". Indeed, suburbs were the ideal places for Nixon to mobilize the "silent majority" and served as the social foundation for Reagan's conservative resurgence. However, subsequent economic and social development has gradually changed the sources of wealth, demography, and educational and cultural preferences in the suburbs. Especially since the coming of the globalization era, an increasing number of members of the suburban middle class has joined the high-end service sector and become accustomed to social diversity and cultural tolerance and exchange. However, in the process of globalized income distribution, they have also developed a strong sense of deprivation because a disproportionate amount of wealth, especially capital income, has been claimed by the top 1 percent and the gap between them and the high-income class has widened to an insurmountable extent. The weakening of social mobility and the end of the American dream not only haunt the underclass but also increasingly trouble the middle. As Chris Hayes, a well-known political commentator, sees it, the OWS movement set new social boundaries that accurately separate the well-educated but relatively toothless middle class from the ultra-rich top few (Hayes 2017). Even upper-middle-class households have begun to criticize institutional favoritism and question elite groups. They blame the top few for distorting rules in the guise of deregulation and undermining fair competition through government-business collusion. Trump initially promised to "drain the swamp" and break the monopoly of the establishment, which attracted the middle class. However, after he took office, he did not curb corruption in Washington, and power-for-money deals became even more extensive. The president himself refused to put his family assets 
into an independent blind fund, and his family members did not shy away from managing White House policies and family business at the same time, resulting in recurrent doubts and even scandals. Officials appointed by Trump followed suit, blending public and private interests or even abusing public power for personal gain before going through the revolving door, causing strong discontent among the suburban middle class. At the same time, Trump's policy of moving the manufacturing industry back home was incompatible with the economic rationality of the middle class, which understands the necessity and possibility of upgrading the American industry and finds it hard to accept the Trump administration's moves to disturb the global economic order. In the 2018 midterm elections, the suburban middle class moved away from the Trump camp to support progressives, attracting wide attention (Tyson 2018). The most dramatic example of this occurred in Orange County, California, which was once praised by Reagan as a conservative bastion where "all the good Republicans go to die". In 2016, four out of Orange County's six seats in the House of Representatives belonged to the Republican Party; by 2018, all six were taken by Democrats.

The aforementioned groups supporting American progressive politics in the new century overlap, as they are defined in different terms. Besides these groups, smaller communities of the highly educated, the intelligentsia, and the socially disadvantaged also support political reforms and progress in the US.

\section{Obstacles to American progressive politics}

Although the progressive movement has a broad base and has gained momentum in recent years, it has not yet been able to set the agenda for American political discussion. In fact, the opportunity to initiate progressive changes was lost during the 2020 election. The reasons behind this lost opportunity are intriguing.

First, in the diverse progressive camp, there are subtle but important differences in views concerning prioritization between economic and sociocultural issues. Some believe that equal economic opportunity is the foundation for equal social rights and that a multicultural policy will be viable only after economic prosperity is restored and shared. Others pay more attention to securing social rights for vulnerable groups, especially African American communities, believing that the elimination of systemic suppression and discrimination should be prioritized when basic personal safety is not effectively protected. Though Biden's choice of Kamala Harris as his running mate has attracted support from some progressives, it has also been criticized as playing into identity politics. In essence, disagreement within the progressive camp has given the Democratic establishment the opportunity to dominate party discourse.

Second, as the target of progressive reforms, plutocrats, though few in number, have leveraged their formidable strength and deep-rooted complex institutional arrangements to safeguard their vested interests, acting swiftly and efficiently against progressive politics. The meticulous work by right-wing conservatives for nearly half a century has given plutocrats skill and ease in handling social and cultural debates and the edge on social and economic issues. Despite President Trump's 
habitual claim that liberal bias pervades the US media, the truth is that views that are pro-market and pro-capital, oppose government regulation, and question social redistribution are clearly dominant in discussions on economic policy. In such an atmosphere, the policies of progressive leaders have been disproportionately criticized. The Green New Deal advocated by AOC is described as a utopian dream that stifles economic growth. Sanders' Medicare for All plan is blamed to drive the federal government bankrupt. And scholarly Warren has been unfairly scrutinized for advancing various proposed practical solutions and was accused of being unable to secure funding for her Medicare for All plan. In contrast, Trump could afford to consistently ignore economic details when he protected the traditional energy industry and disregarded the new energy industry, and he easily resisted being blamed for disrupting economic order when he abolished Obamacare without offering any alternative plan. Trump's 2017 tax cut bill brought the US fiscal deficit back to trillion of dollars per year even in the so-called boom period before the COVID-19 pandemic. However, as long as the right-wing repeats the assumption that tax cuts promote economic growth, expand the tax base, and thus lead to the decrease and gradual disappearance of deficits no matter how huge they are, few members of the media will ask questions about Trump's responsibility in breaching fiscal discipline.

A historical review reveals an even sharper contrast. After anti-monopoly and anti-trust slogans were put forward by the Progressive Movement in the early twentieth century, industrial oligarchs soon were on the defense. Monopoly enterprises in transportation, energy, and public utilities were either demerged or restricted, and government regulations were smoothly launched and progressive taxation for equal redistribution was written into the US Constitution in the form of an amendment. However, in the public discussion of progressive policies in the twenty-first century, Warren and Sanders' proposals to break up large financial institutions and tech companies have met strong resistance. Various unicorn companies insist that they do not hinder competition and blame regulatory authorities for destroying the free market. Today's big capital relies on the organizational resources, intellectual resources, and political networks accumulated since the Reagan Revolution, as well as the central position of the finance industry in the US economy since the start of economic globalization. Longstanding excessive financialization has changed American industries and corporate culture. The evaluation of enterprises based on capital gains has caused an imbalance between production and financing. Financial mentality has replaced economic rationality in dominating policy discussions, and the super-rich have taken the most returns on assets, creating a strong fortress of vested interests. During the 2007-2008 financial tsunami for which they were directly responsible, big capitalists saw their wealth grow. During the unexpected crisis caused by the COVID-19 pandemic, they have once again made huge fortunes amid economic turmoil. According to the Billionaire Bonanza 2020 report prepared by the Institute for Policy Studies, the total personal wealth of the 643 richest Americans increased by 29\% from March to September 2020 (Alcorn 2020). Such incredible financial capacity allows plutocrats to suppress with ease the challenge posed by progressives. When voices in the US Congress called for restricting stock repurchases, Goldman Sachs issued a public report warning about the danger of a stock market crash (Wang 2019). When Sanders took the lead in the Democratic primary, the so-called Bernie 
Sanders Panic Index was constructed, posing an implicit threat that the Democratic Party would be opposed by big capital if it chose Sanders.

Third, progressive propositions in the new century have failed to win broad support from the American underclass, with a large number of members of the white underclass standing in opposition to them. This phenomenon has aroused hot debate in academic and policy circles since Trump won the 2016 election. A popular explanation is that the cultural identity of the white underclass overwhelms members' economic rationality. They are attracted to social topics manipulated by capitalists and rightists. The issue of race in particular stirs up fear and hatred, making the grassroots tool for the ultra-high-income group to counter progressive reforms. A more refined study may suggest that members of the white underclass do not stand against their own interests, as their socioeconomic situation in the Progressive Era of the twentieth century was quite different from their situation today. In this sense, the successful reforms of the twentieth century have become a stumbling block for progressive policy in the new century. Thanks to the social safety net built from the 1910 s to the 1930s, the basic living situation of disadvantaged whites is secure. Even after reform of "welfare politics" was proposed during the Reagan Revolution, the social security responsibility undertaken by governments at all levels has not been significantly affected, and the government regulation system developed from the Progressive Era to the New Deal still effectively secures a supportive environment for small and medium-sized enterprises and ensures the basic supply of public goods. With their survival secure, members of the white underclass, especially those living in inland villages and towns, are not keenly aware of the economic insecurity so vehemently attacked by new progressives and do not have the same sense of urgency as 100 years ago to actively address income redistribution. As a result, the success of progressive reforms in the twentieth century has become a stumbling block for progressive policies in the twenty-first century.

Similarly, some members of the lower-middle class have rather complex feelings towards the economy. The reform of the American corporate system after the New Deal provided the middle class with the chance of promotion within large enterprises. In the context of economic globalization, it is very difficult for small and medium-sized enterprises to grow to a scale that allows them to counter industrial monopolies. In some high-end services, however, they are able to earn a place in the industrial chain by relying on the property rights institution or expect economic benefits through mergers and acquisitions. Anti-monopoly slogans were well received a hundred years ago because they catered to the traditional pursuit of economic freedom and entrepreneurship. In contrast, diversified upward mobility in social strata today makes the lower-middle class indecisive. Despite frequent visits to Rust Belt states, Sanders failed to convince the majority of the lower-middle class to join his "revolution". ${ }^{2}$ This precisely reflects the disconnect between the political passions of progressive leaders and grassroots anxieties over personal gains and losses.

In short, American progressives in the twenty-first century face an uphill battle. They have a broad support base, though their supporters have implicit differences

\footnotetext{
2 The "revolution" here is quoted from Sanders' own conceptual description. See Sanders (2018).
} 
among themselves. The opposition is a strange combination of the ultra-rich and the white lower-middle class, but it is more fully mobilized and has abundant resources. Even within the Democratic Party, it is difficult for progressives to develop momentum to assure victory. It is therefore only natural for progressives to concede to the weightier desire to defeat Trump.

\section{Changes in social background}

A long-term historical perspective and broad global horizon highlight a rather unfavorable environment for American progressive politics in the new century, especially in comparison to that of the Progressive Movement in the early twentieth century.

First, the historical features and political system design of the US are more conducive to meeting the challenges of modernization than to overcoming difficulties related to globalization. While economic and social modernization creates temporal fractures, globalization causes geospatial separation (or non-geographical recombination) while creating virtual spaces. As described by Professor Dani Rodrik, the social and cultural gap between international metropolises and rural towns is widening (Rodrik 2019). The US and its political system were established on the basis of relatively simple social stratification, with only mild historical and cultural burdens in comparison to Eurasian countries. For this reason, during the economic modernization process in the late nineteenth century and the subsequent progressive reforms in the early twentieth century, the United States was able to easily get rid of the constraints of pre-modern historical routes, boldly establish innovative institutions, and address modernization issues in a flexible manner.

In the context of the global economy, the US federal system of checks and balances has become a major obstacle to overcoming geospatial divisions. The Bible Belt has been controlled by Christian fundamentalists for a long time, and anti-science education prevails in the region. To boycott the civil rights movement, some local authorities in southern states advocated regional autonomy in many areas, including public security, education, and social equality, and even denounced the end of apartheid as a "conspiracy of liberal intellectual elites", leading to a distorted interpretation of history (Jacoby 2018, 153-154). Since the delegation of power to states under the banner of "new federalism" during the Reagan administration, although the conservative right-wing has been unable to change the trend of more equal rights across the United States, it has, within the scope of local power, intensified the sense of fear among the white underclass through emphasizing controversial issues such as reproductive rights and equality for sexual minorities and created a set of anti-intellectual narratives. ${ }^{3}$ As the federal government does not have the

\footnotetext{
3 As Susan Jacoby argues, the collapse of American middle-class culture after the 1960s is the result of the impact of both the left and right wings. The conservative right wing of the United States holds even greater responsibility for the loss of the sense of history and global perspective among many Americans. See Jacoby (2018, 102-131).
} 
power to implement unified education standards from the top down, basic science, civic knowledge, and social consensus have not been instilled in inland conservative regions for nearly half a century. Backward education and lack of human capital have left these regions behind in the globalization era, and discontent with being abandoned by the times in turn has strengthened cultural conservatism, reinforcing a closed loop of being left behind and resisting progress. It is not surprising that the progressives of the twenty-first century have found it hard to build a nationwide grassroots coalition similar to that of a hundred years ago.

Second, with the penetration of the internet, the information technology era moved from a first stage of equality and empowerment to a second stage characterized by a significant long tail effect ${ }^{4}$ roughly between 2008 and 2012, when smart phones became popular and social networks changed channels of mass communication. The previous stage saw an increase in cross-boundary social and political dialogue, exchanges, and brainstorming. In contrast, the current stage features the aggregation and closure of marginalized groups, leading to information cocoons, mutual exclusion, and difficulty in building mainstream consensus. This in turn has given rise to the fragmentation of public opinion and has changed the rules of political dialogue. As pointed out by American journalist Franklin Foer, Facebook and other technology unicorns have adopted algorithms that replace causality arguments with simple correlations. These algorithms exclude real thinking and logic from the learning process with immediate impact (Foer 2019, 57). While the influence of careful reflection, great discernment, and profound insight has been weakened, self-styled populist leaders have gained a greater ability to fuel fanaticism among minority groups through common hoaxes and have sustained fevered imagination in echo chambers created by technology. Philosophers (such as Henry George, Lester Ward, and Edward Bellamy) (Zi 2007, 35-48) who once inspired American grassroots activism during the Progressive Era a hundred years ago would likely be defeated by William Sumner's Social Darwinist slogans in today's public opinion environment. When Mark Zuckerberg and Jeff Bezos shake the authority of the mainstream media and refuse to take on the responsibility of a news gatekeeper, ${ }^{5}$ it is no wonder that "alternative facts" flood the public opinion field. As progressive leaders cannot convey accurate information and mature ideas to grassroots individuals, it is naturally very hard for them to gain an upper hand in political debates.

Third, the dramatic changes in the relations between the US and the rest of the world over the past hundred years have put American progressive forces on the defensive. A hundred years ago, the Progressives represented the trend of the times; today, progressives have no allies abroad and have to seek change at disadvantage at home. From the second half of the nineteenth century to the early twentieth century, the US regarded itself as a part of world politics and a latecomer in industrialization

\footnotetext{
4 The long tail effect can be interpreted as relying on the development of new technology, gathering scattered marginalized groups, and building a political force that shakes mainstream policy without eliminating differences and misunderstandings.

5 It is said that Bezos once said in a letter to investors: "Even the well-intentioned gatekeeper will be a drag on innovation." See Foer $(2019,86)$.
} 
and modernization. It was curious about various explorations in Europe on issues such as political reform, economic management, and municipal reform, and learned modestly from scholars of other countries in discussions on philosophies and ideas. As famous historian Richard Hofstadter notes, first-class American scholars at that time pursued cosmopolitan knowledge. Their ideologies were deeply shaped by major European social theorists, and they were keenly aware of the position and responsibility of the US in the new global environment (Hofstadter 2019). The progressive reforms that they later launched in the US not only conformed to the trend of world politics, but also guided changes in world politics due to their practicality and innovation (Rodgers 2011).

In the second half of the twentieth century, as the US became dominant in the international arena, the mentality of its leadership changed greatly. American leadership has been lost in complacency and has become accustomed to being the leader of world politics, ignoring changes of other countries and being unwilling to learn from others. In addition, the ideological confrontation that took place during the Cold War still has an imprint on American mentality, and the country expresses deep doubt and hostility toward "non-American" ideologies and social experiments. Ironically, American conservatives have been the main players in provoking confrontation in the ideological and cultural realms. During the height of the Cold War from the 1950s to the 1960s, they successfully stigmatized mainstream liberalism by investigating "suspicious relations" with the European left-wing. In the 1980s, propaganda on "historical confrontation with the Soviet empire" put these conservatives in a superior position in the domestic political arena. Since the end of the Cold War, they have launched a neoconservative campaign by way of anti-terror warfare. The conservative right-wing has transformed traditional American exceptionalism into a theory in which American superiority serves as the best shield for refusing to learn from the experiences of other countries (Friedman 2020). Under these circumstances, progressives may seem out of the place if they keep talking about foreign experiences or trends and changes in the world, as their predecessors did a hundred years ago. In the midst of boasted greatness, efforts made to acknowledge flaws and promote reforms are easily suppressed.

\section{Conclusion}

Progressive politics is not necessarily a magic formula that will resolve social and economic problems in the US today, nor is it the only way to break through the country's political deadlock. However, the fact that twenty-first century progressive politics in the US has been repeatedly frustrated and suppressed by significantly less refined policies reflects the fatigue present in the American system and culture. In the global context, the unfavorable situation for progressive reforms in the US is thought-provoking. If world politics loses its direction or, even worse, turns in a wrong direction, it will be extremely difficult to build a peaceful and prosperous international order. In this sense, the challenges in American politics have universal significance. How the US will respond to progressive proposals is 
of considerable importance to other countries, and its ultimate choice is bound to influence the future of the world.

\section{Declarations}

Conflict of interest The author declares that there is no competing interest regarding the publication of this article.

\section{References}

Alcindor, Yamiche. 2020. What to expect from Gen Z voters in 2020 elections. PBS Newshour. https:// www.pbs.org/newshour/show/what-to-expect-from-gen-z-voters-in-2020-elections. Accessed 10 Oct 2020.

Alcorn, Chauncey. 2020. US billionaire wealth increase in pandemic. CNN. https://www.cnn.com/ 2020/09/17/business/us-billionaire-wealth-increase-pandemic/index.html. Accessed 10 Oct 2020.

Brown, Clair, and Simon Sallstrom. 2019. What America needs to understand about capitalism. Project Syndicate. https://www.project-syndicate.org/commentary/america-presidential-election-reformcapitalism-by-clair-brown-and-simon-sallstrom-2-2019-07. Accessed 10 Oct 2020.

Cassella, Megan. 2020. "A tale of 2 recessions": As rich Americans get richer, the bottom half struggles. Politico. https://www.politico.com/news/2020/09/07/income-inequality-wealth-gap-409234. Accessed 10 Oct 2020.

Democratic National Convention. 2020. 2020 Democratic Party Platform. https://www.demconvention. com/wp-content/uploads/2020/08/2020-07-31-Democratic-Party-Platform-For-Distribution.pdf. Accessed 10 Oct 2020.

Foer, Franklin. 2019. World without mind: the existential threat of Big Tech (没有思想的世界: 科技巨头 对独立思考的威胁), trans. She Qi [舍其]. Beijing: CITIC Press.

Forgey, Quint. 2020. Biden, Sanders name leaders of their "unity task forces". Politico. https://www.polit ico.com/news/2020/05/13/biden-sanders-unity-task-forces-leaders-aoc-254456. Accessed 10 Oct 2020.

Friedman, Yuri. 2020. Coronavirus could end American exceptionalism. The Atlantic. https://www. theatlantic.com/politics/archive/2020/05/coronavirus-could-end-american-exceptionalism/611605/. Accessed 10 Oct 2020.

Hayes, Christopher. 2017. Twilight of The Elites: America After Meritocracy (精英的黄昏: 后精英政治 时代的美国), trans. Zhang Yuhong [张宇宏]. Shanghai: Shanghai Translation Publishing House.

Hofstadter, Richard. 2019. The age of reform. Quoted from Thomas Bender. A nation among nations: America's place in world history (万国一邦. 美国在世界历史上的地位), trans. Sun Xiu [孙琇], 310-311. Beijing: CITIC Press.

Huntington, Samuel. 2017. American Politics: The Promise of Disharmony (美国政治: 激荡于理想与 现实之间), trans. Xian Mengqi [先萌奇], and Jing Weiming [景伟明]. Beijing: Xinhua Publishing House.

Jacoby, Susan. 2018. The age of American unreason (反智时代: 谎言中的美国文化), trans. Cao Yufei [曹聿非]. Beijing: New Star Press.

Khalid, Asma. 2020. Why Progressives chose Bernie Sanders over Elizabeth Warren. NPR. https://www. npr.org/2020/03/07/812903782. Accessed 10 Oct 2020.

Kurtzleben, Danielle. 2019. Here's how Warren finds \$20.5 trillion to pay for "Medicare For All". NPR. https://www.npr.org/2019/11/01/775339519. Accessed 10 Oct 2020.

PBS Newshour. 2020. Biden, Harris aim to tip battleground Arizona for Democrats. https://www.pbs. org/newshour/politics/watch-biden-harris-aim-to-tip-battleground-arizona-for-democrats. Accessed 10 Oct 2020.

Nilsen, Ella. 2020. How Joe Biden and Bernie Sanders joined forces to craft a bold, progressive agenda. Vox. https://www.vox.com/21317850/joe-biden-bernie-sanders-task-forces-progressive-agenda. Accessed 10 Oct 2020. 
Palmer, Ewan. 2019. Popularity of socialism spiking in U.S., with 43 percent now saying it would be good for the country. Newsweek. https://www.newsweek.com/socialism-america-gallup-poll-14312 66. Accessed 10 Oct 2020.

Peoples, Steve. 2019. Warren has her own plan for everything - except this. ABC news. https://abcnews. go.com/Politics/wireStory/warren-plan-65608375. Accessed 10 Oct 2020.

Pew Research Center. 2008. Young voters in the 2008 election. https://www.pewresearch.org/2008/11/13/ young-voters-in-the-2008-election/. Accessed 10 Oct 2020.

Prokop, Andrew. 2020. The Democratic platform explained: What's in the platform, what's controversial about it, and what it all means. Vox. https://www.vox.com/2020/8/18/21322685/democratic-conve ntion-platform-controversy. Accessed 10 Oct 2020.

Robinson, Nathan. 2020. The time is ripe for more socialism. Newsweek. https://www.newsweek.com/ time-ripe-more-socialism-opinion-1505473. Accessed 10 Oct 2020.

Rodgers, Daniel. 2011. Atlantic crossings: social politics in a progressive age (进步时代的社会政治), trans. Wu Wanwei [吴万伟]. Nanjing: Yilin Publishing House.

Rodrik, Dani. 2019. Tackling inequality from the Middle. Project Syndicate. https://www.project-syndi cate.org/commentary/tackling-inequality-from-the-middle-by-dani-rodrik-2019-12?barrier=acces spaylog. Accessed 10 Oct 2020.

Sanders, Bernie. 2018. Our Revolution: A Future to Believe In (我们的革命:西方的体制困境 和美国的社会危机), trans. Zhong Shuting [钟舒婷], and Zhou Zijun [周紫君]. Nanjing: Jiangsu Literature and Art Publishing House.

Tarlov, Jessica. 2020. The Democratic Party platform represents our big tent. The Hill. https://thehill. com/opinion/white-house/512716-the-democratic-party-platform-represents-our-big-tent. Accessed 10 Oct 2020.

Teixeira, Ruy. 2010. Demographic change and the future of the parties. American Progress Action. https://www.americanprogress.org/wp-content/uploads/issues/2010/06/pdf/voter_demographics.pdf. Accessed 10 Oct 2020.

Tyson, Alec. 2018. The 2018 midterm vote: Divisions by race, gender, education. Pew Research Center. https://www.pewresearch.org/fact-tank/2018/11/08/the-2018-midterm-vote-divisions-by-race-gender-education/. Accessed 10 Oct 2020.

Wang, Lu. 2019. Goldman considers a world without buybacks. Bloomberg. https://www.bloomberg. com/news/articles/2019-04-08/goldman-considers-a-world-without-buybacks-it-looks-ominous. Accessed 10 Oct 2020.

Zi, Zhongyun [资中筠]. 2007. America in the Twentieth Century (20世纪的美国). Beijing: SDX Joint Publishing Press 